\title{
A Framework of Halal Certification Practices for Hotel Industry
}

\author{
Mohd Rizal Razalli ${ }^{1}$, Rushami Zein Yusoff ${ }^{1} \&$ Maizatul Wahidar Mohd Roslan ${ }^{1}$ \\ ${ }^{1}$ School of Technology Management and Logistics, Universiti Utara Malaysia, Kedah, Malaysia \\ Correspondence: Mohd Rizal Razalli, School of Technology Management and Logistics, Universiti Utara \\ Malaysia, Kedah, Malaysia. Tel: 60-4928-7130. E-mail: rizal@uum.edu.my
}

Received: April 22, 2013 Accepted: June 12, 2013 Online Published: August 30, 2013

doi:10.5539/ass.v9n11p316 URL: http://dx.doi.org/10.5539/ass.v9n11p316

\begin{abstract}
Over the past several years, the Muslim population is growing at the faster rate than the non-Muslim population. The increasing population has resulted in demand for the Halal hotels to grow solidly and quickly. Most of the hotels need to take a holistic approach in obtaining the Halal certification for their service operations practices. In addition, research towards Halal certification practices in hotel industry has rarely been studied. Information search for practicing Halal in the hotel industry is somewhat challenging because most of hotels are reluctant to share in depth information on how they perform Halal practices in the organization. Hence, this research aims to develop a model of Halal certification practices. This research also aims to examine how Halal certification practices affect hotel performance. The Halal certification practices were measured by 12 items. The 12 items of Halal certification practices identified included - (1) Halal Documentation, (2) Management Responsibility, (3) Raw Material, (4) Location, (5) Exterior Area, (6) Premise, (7) Facility, (8) Tools and Equipment, (9) Staff Characteristic, (10) Staff Policy, (11) Pest Control, and (12) Waste Management. 60 questionnaires were distributed to staff of EDC-UUM. 54 responses were returned, which representing $90 \%$ response rate. The data was analyzed using factor analysis, reliability analysis, descriptive statistic, and regression analysis. The findings depicted that facilities and staff policy to have significant effects on hotel performance. The other 10 practices were found to have no effect on the hotel performance.
\end{abstract}

Keywords: Halal certification practices, hotel performance, facilities, staff policy

\section{Introduction}

Malaysia is one of the Asia's most popular tourist destinations. According to the Asean Travel and Tourism Competitiveness Report 2012, Malaysia is one of the world's top 10 destinations, with about 25 million visitors per year (BERNAMA, 2011). In addition, Malaysia Tourism Industry also reported that Malaysia received around 24.6 million from international tourists in 2010 compared to only 5.5 million tourists in 2009 , representing an increase of around 347 percent over tourist arrivals. In this context, Muslim tourist is seen to be the highest growth rate of international tourist arrivals in Malaysia. Statistics from Malaysia Tourism Industry indicate that Muslim tourists spent 4,735,775 million in 2007 to 5,784,884 million in 2010, which represented approximately 23.5 percent from the total tourist arrivals in Malaysia in 2010 (BERNAMA, 2011). Majority of these Muslim tourists were from Middle East, Iran, Indonesia, Singapore, Brunei, Pakistan, Bangladesh and Turkey.

With this growing Muslim tourist, the demand for the Islamic-oriented hotel has increased over the years. By 2005 onwards, the Islamic-oriented trend hotels has spilled over, with a number of hotels positioning themselves as Islamic-oriented hotels, such as Caprice Hotel in Turkey, Al-Jawhara Hotel in Dubai, Hotel Sofyan and Hotel Tuara Natama in Indonesia and DePalma Hotel in Malaysia. Adopting the Islamic-oriented theme, these hotels do not serve alcohol drink and non-Halal food. Food products served in the restaurants have to be Halal. In other words, the hotel will provide facilities, support survices and food which meet Islamic requirements. The Islamic concepts have received good response not only from the Muslim guests, but the hotel clients also come from Europe, Germany, Astraulia as well, hence dismissing the perception that Islamic concept hotels are likely to only attract Muslim guests.

The demand of Halal food and Islamic-oriented hotel has lead Malaysia government to believe that the country can become an attractive destination not only from Muslim travelers, but also from non-Muslim travelers. In Malaysia especially, the increasing numbers of Islamic-oriented hotel have positive and significant influence on 
the country. From a perspective of economic survival, Malaysia can create economic involvement and ensure economic sustainability. In addition, the growing numbers of Islamic-oriented hotel also can create a job opportunity for the local people.

Hence, it is necessary for hotel in Malaysia to take a holistic approach in serving Muslim needs. The standards of procedures in the hotels that have been practiced need to comply with the Halal certification. A study conducted by Rajagopal, Ramanan, Visvanathan and Satapathy (2011) indicates that Halal certification can be used as a marketing tool in promoting the Halal brand/products or services. According to Zailani, Omar and Kepong (2011), hotels with Halal certification in their kitchen and premises can give an added competitiveness advantage to the hotels in attracting not only the foreign but also the local tourists.

In Malaysia, Halal certification is certified by Department of Islamic Development Malaysia (JAKIM) and other government agencies such as State Islamic Religious Department (JAIN) and State Islamic Religious Council (MAIN). However, statistics released by JAKIM in 2010 showed that there were only 390 hotels awarded with Halal certification. The number of the Halal certification Hotel/ Kitchen Hotel/ Restaurant Hotel issued by JAKIM was 131 hotels and the other 259 hotels were issued by JAIN. Meanwhile, more recent statistics in 2011 also showed that out of 1,574 hotels and resorts in the country, only 366 or 23 percent were awarded with Halal certification for the food served in their premises. Of the 366 hotels and resorts, 273 or 74.59 percent were those rated between three to five stars, 53 (14.48 percent) were between one to two stars while the other 40 (10.93 percent) were budget hotels and resorts (JAKIM, 2012).

Based on the above statistics, it is timely to do research on the model of Halal certification and effectiveness of Halal certification practices especially on hotel performance. Thus, the objective of this research is to develop a framework of Halal certification practices and investigate how these practices affect hotel performance. The findings of this study can help hotels management to improve their initiatives in the Halal certification processes. In addition, it can be the benchmarking tool for other hotels, organization or industry to pursue for Halal certification.

\section{Literature Review}

\subsection{Concept of Halal}

Islam teaches its followers to consume only the permitted products (Halal and wholesome products). According to the Islamic dietary laws, there are three main categories of food for Muslims: Halal, Haram and Mushbooh (Syubha). The word of Halal originated from the Arabian words of Halla, Yahillu, and Hillan. Halal in an arabic term meaning permissible, allowed or lawful (Yusoff, 2004). The opposite of Halal is Haram which means prohibited, forbidden or unlawful, while Mushbooh (also referred to as Syubha, Shubhah, and Mashbuh) means questionable, doubtful and therefore should be avoided. Mashbooh foods can be produced from Halal or Haram sources. When the specific source is not known, the foods are suspect or questionable. Lawful and unlawful in Islam has been understood by the Muslim community with the clear and distinct because both have been mentioned in the Quran and Hadith. In the verse Quran al-Baqarah: 168, Allah said:

"Oh Mankind! Eat from the earth which is Halal and Tayyib and follow not the footsteps of the devil. He is an open enemy for you".

From Abi 'Abdillah al-Nu'man bin Bashir r.a. said, Rasullah s.a.w said:

"Halal is clear and Haram is clear, in between these two is certain things that are Syubhah (suspected). Many people may not know whether those items are Halal and Haram. Whosoever leaves them, he is innocent towards his religion and his conscience".

In terms of Department of Islamic Development of Malaysia (JAKIM), Halal is defined as a description of things or actions permitted by Shariah law without punishment imposed on the doer (JAKIM, 2012). Halal food means food permitted under the Shariah law and fulfils the following conditions:

* Does not contain any parts or products of animals that are non-Halal to Muslims or products of animals which are not slaughtered according to Shariah law.

- Does not contain any ingredients that are najis according to Shariah law.

- Safe and not harmful.

* Has not been prepared, processed or manufactured using equipment that is contaminated with things that are najis according to Shariah law. 
* The food or its ingredients do not contain any human parts or its derivatives that are not permitted by Shariah law.

* During its preparation, processing, packaging, storage or transportation, the food is physically separated from any other food that does not meet the requirements stated above, or any other things that have been decreed as najis by Shariah law.

\subsection{Halal Certification Practices}

In Malaysia, the Department of Islamic Development of Malaysia (JAKIM) is the competent authority being responsible for Halal certification. JAKIM has been appointed as an authoritative body or organization that being responsible in handling local and international Halal certification process. The responsibility of JAKIM in ascertaining the Halal status of the products involved not only on the official site inspection of plants but also on the examination on how the Halal status of the raw material is maintained and monitored at all times. In view of many raw material used in local food production are mostly imported products which requires the appointment of reputable and reliable foreign Halal certification bodies or organizations to monitor the Halal status of these raw materials. The recognition is also extended to Halal status of finished products (JAKIM, 2012).

In carrying out its role, JAKIM also collaborates with other government agencies such as State Islamic Religious Department (JAIN) and State Islamic Religious Council (MAIN). Under the collaboration, JAKIM has the authority to certify $\boldsymbol{H a l a l}$ certification for Halal products for exports and imports whereas JAIN and MAIN only issue Halal certification to companies producing products and services for the local consumption using the same Halal logo.

According to JAKIM (2012), Halal certification is defined as a process to obtain Halal certification through several steps to prove materials and production process are complied with the standard of Islamic principles. In the point of view of JAKIM, Halal certification is important as it is the sole identifying mark that the product meets the Halal requirements. Besides that, JAKIM also had listed four benefits of Halal certification; 1) consumer confidence which allows the consumers to make an informed choice of their purchases; 2) give competitive advantage, where the manufacturers can use it as a marketing tool; 3) quality aspect - it indicates that the products not only fulfils Halal requirements, but also follows strict hygiene practices; 4 ) as for authority - it provides a mechanism to audit and monitor Halal products.Zailani, Omar and Kepong (2011) indicate Halal food certification as the examination of food processes starts in its preparations, slaughtering, cleaning, processing, handling, disinfecting, storing, transportation, as well as the management practices.

In this paper, Halal certification practices refer to the hotel initiative/activities and behaviors towards managing the Halal certificationand ensuring that these practices are used in achieving the Halal certification for the hotel. These practices would include Halal documentation, management responsibility, raw material, location, exterior area, premise, facilities, tool and equipment, staff characteristic, staff policy, pest control and waste management.

\subsubsection{Halal Documentation Practices}

Halal documentation is necessary documents needed by a new company which wants to obtain Halal certifications (Noordin, Noor, Hashim, \& Samicho, 2009). Halal documentation is a documents explaining the manufacturing processes and procedures such as HACCP and GMP, name/s and address of manufacturer/s or supplier/s of ingredients, the products to be certified and regions in which the products will be sold/marketed along with specific information about the component ingredients (JAKIM, 2012; Rahman, 2008). In this research, the term Halal documentation refers to the activities and behaviors of hotel in providing the Halal documents containing information such as company's profile, registration of company, documents control, standards operating procedures and processing, administration system, and training program.

\subsubsection{Management Responsibility Practices}

Management responsibility refers to the activities and behaviors of hotel management in establising the committee which consists of Muslim personnel who are responsible to ensure the effectiveness in implementation of internal Halal control system (Halal Industry Development Corporation, 2008). The company shall appoint Muslim Halal executive officer to handle and ensure Halal procedures are complied. The management shall also ensure that they are trained on the Halal principles and its application. The owner of Halal certificate is required to train staff and understand the Malaysian Halal Certification Manual Procedure and required to attend training on Halal certification. Finally, the management shall ensure that sufficient resources (i.e. manpower, facility, financial and infrastructure) are provided in order to implement the Halal control system. 


\subsubsection{Raw Material Practices}

Kolovoes (2006) stated that raw material is a basic substance in its natural, modified or semi-processed state that has been used for manufacturers as an input to a production process for subsequent modification or transformation into finished products. Processing of Halal food is referred to the source of Halal food and drink. The content of raw materials, processed materials or additives must be Halal. The hotel needs to provide the food ingredient and additives that should be Halal and supplier or sub-contractors which supply these materials should have Halal certification. List of these materials should be same as declared in the application form. Chicken, ducks and the like should be obtained from supplier / slaughtering house which already acquire Halal certificate (HDC, 2008).

\subsubsection{Location Practices}

It is important to industries to locate their firm in the most sustainable locations (Cooke, Heidenreich and Braczyk, 2004). The location may affect innovation activities, production process, and efficiency. In order to obtain the Halal certification, the premises/hotel shall effectively separate in a distance of 5 Kilometers radius and well insulated from pig farm and waste disposal area to prevent cross contamination through personnel and equipment (HDC, 2008).

\subsubsection{Exterior Area Practices}

Exterior area refers to conditions, entities, events, and factors surrounding an organization that influence its activities and choices, and determine its opportunities and risks. The exterior area is also called the operating environment. In this research, exterior area refers to the activities and behaviors of hotel in providing the areas and surrounding that should be clean and comply with Good Manufacturing Practices (GMP) (HDC, 2008).

\subsubsection{Premise Practices}

HDC (2008) defines premises as an any building or any other structure, permanent or otherwise together with the land on which the building or other structure is situated and any adjoining land used in connection with the preparation, slaughtering, processing, handling, packaging, storage, distribution and sale of any food. In this research, the term premise refers to the activities and behaviors of hotel in providing the building or any other structure such as floor, drainage system, walls, ceiling, doors, window, changing/locker room, lighting system, ventilation and others with a good condition, clean and suitable for the Halal operations. Premise shall be designed and constructed or renovated so as to enable the process flow to control the risk of product contamination and suitable for intended use. Layout of premises shall permit proper process flow, proper employee flow good hygiene and safety practices, including protection against pest infestation and cross-contamination between and during operations. Premises also shall be kept in good repair and condition to prevent pest access and to eliminate potential breeding sites.

\subsubsection{Facilities Practices}

Facilities include the water supply, storage, freezing room, sinks, toilets and transportation that should be sanitaried and cleaned from najs and they are not mixed with other non-Halal materials. For example, transportation vehicle such as bonded truck shall be only dedicated and appropriate to the type of the Halal food and satisfy hygiene and sanitation condition. Besides that, storage for wet and dry raw ingredients should be separated, well-arranged and systematic (HDC, 2008).

\subsubsection{Tool and Equipment Practices}

Tool and equipment is defined as a method of use which signifies that equipment (other than individual equipment) used in furtherance of the common mission of an organization or unit. The tool and equipment in this research, is the activities and behaviors of hotel in providing the devices, utensil, machine and processing aids that should be clean and free from najsorhazardous to health. It means that the devices, utensil, machine, and processing aids used for processing Halal food shall be designed and constructed to facilities cleaning and shall not be made of or contain any materials that are decreased as najs by Shariah law and shall be used only for Halal food.

\subsubsection{Staff Characteristic and Policy Practices}

An organization's effectiveness depends on the knowledge and skill of staff whose develop and deliver services. In this sense, the hotel needs to provide the employees that have practiced good code of work ethics and good hygiene practices (HDC, 2008). The staff is required to have certain vaccination at any health centre approved by the government before or after starting work. All workers shall practice health care and personal hygiene, especially those who work as the production operators. Open wound and ill staff that could affect the product 
quality should not be allowedworking until recover.

Permanent staff, temporary staff, management staff, visitors and others shall wear special clothingaccording to the general health care procedures and personal hygiene procedures. Worker shall at all time maintain personal hygiene and wears proper clothing, hair and mouth cover, gloves and suitable shoes. The company also should assign staff at check point for Halal quality and purchase of Halal raw ingredients. Every staff is encouraged to undergo Food Handlers training and should adhere to safety and cleanliness measures.

\subsubsection{Pest Control Practices}

Pest control is an application and sometimes monitoring of a variety of chemicals used to kill insects \& rodents, usually because it is perceived to be detrimental to a person's health, the ecology or the economy (Kromp, 1999). In this research, pest control refers to the activities and behaviors of hotel in keeping good condition of premise or hotel to prevent pest access and to eliminate potential breeding sites.

\subsubsection{Waste Management Practices}

Waste management is one of the most important environmental issues in developing countries around the world (Begum \& Jacqualine, 2008). Waste management is crucial in reducing the organization's impact upon the environment (Ackerman, 2000). In this research, waste management refers to the activities and behaviors of the hotel in managing the waste and waste disposal area at the premise to achieving efficient cost savings and a better financial return for hotel performance. As described by HDC (2008), the Halal food manufactures shall implement measures to manage waste effectively. Harmful chemical substance should be stored appropriately and away from Halal food.

\subsection{Hotel Performance}

Numerous researchers have started to examine the effects of Halal certificationto hotel performance. Razalli, Abdullah and Yusoff (2012) examined the role of Halal certification in creating organizational competitive advantage and found that Halal certification process have a positive effect on six dimensions of performance which are personnel qualification, employee motivation, multi-skillness of employess, efficiency, environmentally conscious and cost saving.Razalli et al. (2012) argued that in order to achieve green performance, a very well-established Halal certification practice is requiredfor the hotel.

Marzuki, Hall, and William (2012) conducted a quantitative content analysis using the manager's perception of a 33 restaurant in Malaysia. Results demonstrated that Halal certificate is perceived to have an impact on customer trust and return visits. To be effective, Halal certification practices must be aligned with organizational objectives. Marzuki et al. (2012) also argued that Halal certification is very prevalent in the hospitality industry. The proposed framework for Halal certification practices is shown in Figure 1.

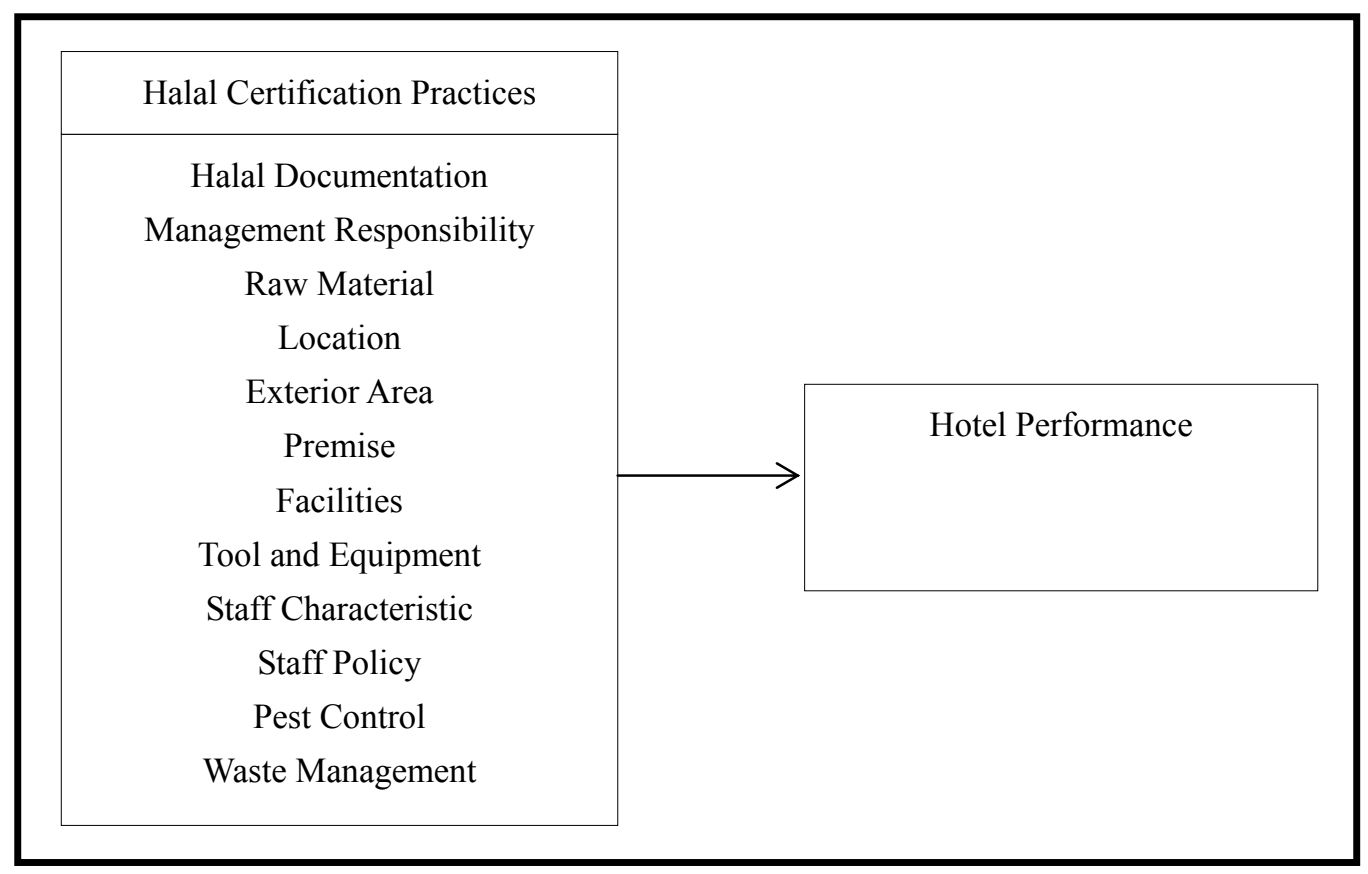

Figure 1. Halal certification practices framework 
The above discussion leads to the following hypotheses:

H1: Halal documentation practice has a significant relationship with hotel performance.

H2: Management responsibility practice has a significant relationship with hotel performance.

H3: Raw Material practice has a significant relationship with hotel performance.

H4: Location practice has a significant relationship with hotel performance.

H5: Exterior area practice has a significant relationship with hotel performance.

H6: Premise practice has a significant relationship with hotel performance.

H7: Facilities practice has a significant relationship with hotel performance.

H8: Tool and equipment practice has a significant relationship with hotel performance.

H9: Staff Characteristic practice has a significant relationship with hotel performance.

H10: Staff Policy practice has a significant relationship with hotel performance.

H11: Pest control practice has a significant relationship with hotel performance.

H12: Waste management practice has a significant relationship with hotel performance.

\section{Method}

\subsection{Sample and Data Collection}

The analysis in this research deals with practices and performance at the hotel level. For the purpose of examining the conceptual model of this research, the data was collected from each staff (both permanent and contract workers) at a university hotel called EDC-UUM. The totalEDC-UUM staff was 60 and it consisted of all the different levels of employees and managers. This research employed purely the quantitative design and data was gathered through the five-point likert scale questionnaire. Questionnaires are the most useful data collection method, especially when large numbers of people are involves (Sekaran, 2000).

The questionnaireconsisted of threemajor sections.The first section (Part A) contains questions about personal profiles of the respondents. The second section (Part B) comprised 12 constructs measuring Halal certification practices and the third section (Part C) comprised 19 items that measured hotel performance. Back to back translation technique was used to translate the content of the questionnairein local language (Malay) and English in order to increase the validity and reliability of thequestionnaire (Wright, 1996). The questionnaire forms were sent personally to the respondents. The respondents were given one week to answer and return the questionnaire to the researcher. A total of 60 questionnaires were distributed to the EDC-UUM staff.Only 54 usable questionnaires were returned from the respondents, representing a response rate of $90 \%$.

\subsection{Statistical Analysis}

To evaluate the present model, Statistic Package for Social Science (SPSS) was utilized for all analyses. Firstly, exploratory factor analysis (EFA) and reliability analysis was used to assess the validity and reliability of the measurement scales (Bryman\&Bell, 2007). Secondly, descriptive statistics was conducted to determine the usefulness of the data set (Muchinsky, 1993).

Finally, regression analysis, as recommended by Sekaran (2003) was done to determine the significant relationship between dependent and independent variables, the direction of the relationship, the degree of the relationship and strength of the relationship. It also leads us to how much those variables can influence the dependent variables and the influence in a positive or negative manner.

\section{Results}

\subsection{Respondents Profile}


Table 1. Respondent's profile

\begin{tabular}{|c|c|c|c|}
\hline & Categories & Frequencies & Percentage \\
\hline \multirow{6}{*}{ Role within Organization } & Senior Management & 6 & 11.1 \\
\hline & Junior Management & 4 & 7.4 \\
\hline & Middle Line & 15 & 27.8 \\
\hline & Non-managerial & 29 & 53.7 \\
\hline & Total & 54 & 100 \\
\hline & 5 Years & 10 & 18.5 \\
\hline \multirow{5}{*}{ Number of Years Working in Organization } & 4 Years & 3 & 5.6 \\
\hline & 3 Years & 8 & 14.8 \\
\hline & 2 Years & 5 & 9.3 \\
\hline & 1 Years and less & 28 & 51.9 \\
\hline & Total & 54 & 100 \\
\hline \multirow{6}{*}{$\begin{array}{l}\text { Number of Years Working in Hospitality } \\
\text { Industry }\end{array}$} & More than 20 Years & 1 & 1.9 \\
\hline & $15-20$ Years & 1 & 1.9 \\
\hline & 10-15 Years & 3 & 5.6 \\
\hline & 5-10 Years & 9 & 16.7 \\
\hline & Less than 5 Years & 40 & 74.1 \\
\hline & Total & 54 & 100 \\
\hline
\end{tabular}

In relation to the respondent's profile, Table 1 shows the following background: (1) Role within Organization, (2) Number of Years Working in Organization and (3) Number of Years Working in the Hospitality Industry.

Regarding the role within organization, the results indicates that majority of the respondents (53.7 percent) were holding the non-managerial position, 27.8 percent of them were holding middle line position, 11.1 percent of respondents in the senior management position, while 7.4 percent were junior management in the hotel.

In terms of their tenure, most of the respondents had an experience for less than 1 year (51.9 percent), 5 years (18.5 percent), 3 years (14.8 percent), 2 years (9.3 percent) and lastly 4 years (5.6 percent). As for their experience working in the hospitality industry, 74.1 percent of the respondents had less than 5 years of working experience, 16.7 percent had between 5 to 10 years and 5.6 percent had 10 to 15 years of working experience. Meanwhile, only 1.9 percent of respondents had between 15 to 20 years of working experience and the remaining (1.9 percent) had more than 20 years of working experience in the hospitality industry.

\subsection{Exploratory Factor Analysis (EFA) and Reliability Analysis}

EFA is a method of data reduction. It is used to explore the data set to be used in a research from the existing theoretical view, mainly by allowing such data to statistically load on factors that are independent of theory and any a priori assumption that are related to the measurement instruments (Hair et al., 2007).

The questionnaire has 89 items which are related to 12 variables: hotel performance (19 items), Halal documentation (6 items), management responsibility (4 items), raw material (4 items), location (4 items), exterior area (4 items), premise (10 items), facilities (15 items), tool and equipment (5 items), staff characteristic (5 items), staff policy (6 items), pest control (4 items), and waste management (3 items). 
Table 2. Results of EFA and reliability analysis

\begin{tabular}{llllll}
\hline Measures & Items & Factor Loadings & KMO & \% Variance & Alpha \\
\hline Hotel Performance & 19 & $0.822-0.948$ & 0.925 & 84.58 & 0.990 \\
Halal Documentation & 6 & $0.747-0.936$ & 0.841 & 80.09 & 0.950 \\
Management Responsibility & 4 & $0.920-0.943$ & 0.782 & 86.63 & 0.947 \\
Raw Material & 4 & $0.714-0.933$ & 0.809 & 74.76 & 0.887 \\
Location & 4 & $0.918-0.949$ & 0.803 & 86.96 & 0.950 \\
Exterior Area & 4 & $0.923-0.970$ & 0.780 & 89.68 & 0.961 \\
Premise & 10 & $0.753-0.940$ & 0.874 & 78.84 & 0.969 \\
Facilities & 15 & $0.714-0.962$ & 0.921 & 80.45 & 0.982 \\
Tool and Equipment & 5 & $0.823-0.921$ & 0.801 & 80.29 & 0.938 \\
Staff Characteristics & 5 & $0.745-0.899$ & 0.891 & 74.12 & 0.958 \\
Staff Policy & 6 & $0.599-0.903$ & 0.891 & 74.12 & 0.943 \\
Pest Control & 4 & $0.963-0.986$ & 0.852 & 95.26 & 0.983 \\
Waste Management & 3 & $0.978-0.989$ & 0.767 & 96.75 & 0.983 \\
\hline
\end{tabular}

Table 2 shows the results of the EFA analyses where all research variables exceeded the minimum standard of Kaiser-Meyer-Olkin's value of 0.6 as suggested by Kaiser (1974). All individual loadings were above the minimum of 0.5 recommended by Hair, Money, Samouel and Page (2007). This result indicated that all the Halal certification practices constructs were acceptable for further analysis.

Reliability analysis was conducted to measure the reliability of the measurement instrument used in the research. Croanbach's Alphas is a reliability coefficient that indicates how well the items in a set are positively correlated to one another (Sekaran, 2003). Reliability measures above 0.70 are considered to be acceptable for the research purpose (Sekaran, 2003). The results from Table 2 show that each set of variables has a Croanbach's Alpha value range between $0.887-0.990$ which indicated good reliability for the questionnaires. Thus it can be concluded that the measurement used in this study can bedeemed valid and reliable.

\subsection{Descriptive Statistic}

Table 3. Results of mean and standard deviation

\begin{tabular}{lll}
\hline Items & Mean & Std. Deviation \\
\hline Hotel Performance & 3.77 & .93 \\
Halal Documentation & 3.80 & .97 \\
Management Responsibility & 4.00 & 1.06 \\
Raw Material & 3.93 & .99 \\
Location & 4.10 & 1.09 \\
Exterior Area & 4.02 & 1.03 \\
Premise & 3.87 & 1.02 \\
Facilities & 3.92 & .99 \\
Tool and Equipment & 3.95 & .95 \\
Staff Characteristic & 4.19 & 1.12 \\
Staff Policy & 3.94 & 1.05 \\
Pest Control & 3.89 & 1.12 \\
Waste Management & 4.04 & 1.15 \\
\hline
\end{tabular}

Descriptive analysis namely the mean and standard deviation for the independent and dependent variables were attained and recorded in Table 3. All variables were measured on a 5-point Likert scale. For independent variables, the scale range from (1) being strongly disagree to (5) being strongly agree. For dependent variables, the scale ranged from being (1) worse significantly to (5) improved significantly. Table 3 indicates that staff 
characteristic scored the highest (4.19) mean value. This shows that the commitment of management hotel towards staff characteristic initiative was good. This was then followed by location $(M=4.10)$, waste management $(\mathrm{M}=4.04)$, exterior area $(\mathrm{M}=4.02)$, management responsibility $(\mathrm{M}=4.00)$, tool and equipment $(\mathrm{M}=3.95)$, staff policy $(\mathrm{M}=3.94)$, raw material $(\mathrm{M}=3.93)$, facilities $(\mathrm{M}=3.92)$, pest control $(\mathrm{M}=3.89)$, premise $(\mathrm{M}=3.87)$ and Halal documentation $(\mathrm{M}=3.80)$. The lowest mean score was recorded by EDC-UUM performance with the mean of 3.77. The lowest mean value providedevidence that more works need to be done to improve the EDC-UUM performance. In summary, the results showed that all variables were relatively high on the scale with leading to mean of 3.00 to 4.00 , indicating that the response of respondents answered positively to the variables. In addition, the mean scores showed that EDC-UUM hotel were doing quite well in terms of their performance.

4.4 Regression Analysis

Table 4. Results of regression analysis

\begin{tabular}{|c|c|c|c|c|c|c|}
\hline \multirow{3}{*}{$\begin{array}{l}\mathrm{R} \\
.901^{\circ} \\
\text { Mod }\end{array}$} & \multirow{3}{*}{$\begin{array}{l}\text { R Square } \\
.812\end{array}$} & \multirow{2}{*}{$\begin{array}{l}\text { Adjusted R Square } \\
.757\end{array}$} & \multicolumn{2}{|c|}{ Std. Error of the Estimate } & \multirow{3}{*}{$\begin{array}{l}\mathrm{F} \\
14.779 \\
\mathrm{t}\end{array}$} & \multirow{3}{*}{$\begin{array}{l}\text { Sig. F } \\
.000^{\mathrm{a}} \\
\text { Sig. }\end{array}$} \\
\hline & & & .45701 & & & \\
\hline & & $\mathrm{B}$ & Std. Error & Beta & & \\
\hline \multicolumn{2}{|c|}{ Halal Documentation } & .077 & .164 & .081 & .472 & .639 \\
\hline \multicolumn{2}{|c|}{ Management Responsibility } & .054 & .159 & .062 & .341 & .735 \\
\hline \multicolumn{2}{|c|}{ Raw Material } & -.059 & .156 & -.063 & -.380 & .706 \\
\hline \multicolumn{2}{|c|}{ Location } & .046 & .187 & .054 & .245 & .808 \\
\hline \multicolumn{2}{|c|}{ Exterior Area } & -.091 & .232 & -.101 & -.393 & .697 \\
\hline \multicolumn{2}{|c|}{ Premise } & .051 & .217 & .056 & .234 & .816 \\
\hline \multicolumn{2}{|c|}{ Facilities } & .745 & .328 & .798 & 2.271 & .028 \\
\hline \multicolumn{2}{|c|}{ Tool and Equipment } & -.027 & .228 & -.028 & -.120 & .905 \\
\hline \multicolumn{2}{|c|}{ Staff Characteristic } & .111 & .176 & .133 & .628 & .534 \\
\hline \multicolumn{2}{|c|}{ Staff Policy } & .422 & .138 & .477 & 3.057 & .004 \\
\hline \multicolumn{2}{|c|}{ Pest Control } & -.413 & .210 & -.498 & -1.968 & .056 \\
\hline \multicolumn{2}{|c|}{ Waste Management } & -.038 & .197 & -.047 & -.193 & .848 \\
\hline
\end{tabular}

Regression analysis was employed as the way to recognize if there is significant relationship between dependent variable and independent variable. The results of regression analysis among 12 variables against dependent variable, hotel performance can be seen in the Table 4. As shown in Table 4, it was found that the adjusted $\mathrm{R}^{2}$ value was 0.812 , which means that the 81 percent of the variance in hotel performance had been significantly explained by the 12 variables. The result also indicated that $F$ statistic produced $(F=14.779)$ was statistically significant $(0.000)$ at the 0.05 level. It can be concluded that this regression model was statistically significant as the $\mathrm{p}$ value was less than 0.05 .However, in the model, only 2 independent variables were statistically significant namely facilities $(\beta=.798 ; \mathrm{p}<0.05)$ and staff policy $(\beta=.477 ; \mathrm{p}<0.05)$ variables. Thesefindings show that facilities and staff policy variables had the strongest influence on the hotel performance. Therefore the result of the hypotheses testing between Halal certification practices variables and hotel performance indicated that $\mathrm{H} 7$ and $\mathrm{H} 10$ were supported while the remaining 10 hypotheses $(\mathrm{H} 1, \mathrm{H} 2, \mathrm{H} 3, \mathrm{H} 4, \mathrm{H} 5, \mathrm{H} 6, \mathrm{H} 8, \mathrm{H} 9, \mathrm{H} 11$ and H12) were rejected mainly because of their insignificant influence.

\section{Discussion}

This research attempts to establish a framework of Halal certification practices. We have proposed and tested 12 key variables thatcan determine the success of the Halal certification process. Those 12 variables are shown in Figure 1. These variables are viewed in terms of practices, which mean they are perceptual measures on the activities and behaviors of the hotel (management and staff) to comply each dimension with the Halal requirements. Further, we also study the relationships of all the 12 practices and the hotel performance. The findings of this research showed that only 2 variables out of 12 variables of Halal certification practices were positively and significantly related to the hotel performance. The other 10 practices were not significantly related to the hotel performance. Firstly, facilities and hotel performance were found to have significant relationship. The first finding was supported by previous studies by Barrett (1994), Madeley (1996), Amaratunga, Baldry and Sarshar (2000), who found that facilities have a direct relationship with performance. Hence, the Halal 
certification would also affect performance. In this case, we have found that facilities at the premise such as water supply, storage, shelves, freezing room, chemical materials, sinks, toilets and others would enhance the hotel performance. Futhermore, activities in the hotel should be coordinated and all functions in the hotel especially in the kitchen need to comply with the Halal certification.

Secondly, another dimension of halal certification practices, staff policy, was found to have significant relationship with hotel performance. This result is related to Collis and Montgomery (1995), Likert (1961), Salamon (2000), Cascio (1992), who found that staff performance to have a significant positive effect on organizationalperformance. Therefore, to improve performance of Halal certificated hotel, the Halal policy need to be shown adequately for reminder. Furthermore, there should be a good record on food handler training from the human resources management. The staff of hotel should also undergo the typhoid injection accordingly, applying the Good Manufacturing Practices in their operations, and lastly need to be trained adequately in understanding the Halal. The policy related to virus infection should also be available and implemented by the staff.

This research also shows that the other variables of Halal certification practices such as Halal documentation, management responsibility, raw material, location, exterior area, premise, tool and equipment, staff characteristic, pest control and waste management are not significantly related to hotel performance. In other word, any improvements made by hotel on these variables may not give influential impact on the hotel performance.The findings are consistent with the previous study byNoordin et al. (2009), Cooke et al. (2004), Kromp (1999) and Ackerman (2000). Despite these insignificant results, this study contributes the model of Halal certification practices to the academic and practitioners. However, this is the first attempt that the model is being presented and thus further works need to be continuously improved.

\section{Conclusion and Recommendation}

In summary, with regards to the hotel industry, this research has found that EDC-UUM performance is only significantly influenced by two variables of Halal certification practices namely facilities and staff policy. The other variables of Halal practices such as Halal documentation, management responsibility, raw material, location, exterior area, premise, tool and equipment, staff characteristics, pest control and waste management do not have significant relationships with hotelperformance. The hotel industry requires the good Halal certification practices in order to improve their services to stay competitive with other hotels in Malaysia and abroad. In conclusion, the hotel industry must consider the importance of their facilities and policy to persuade their employees to perform the impress services to customers and co-workers to keep the high level performance. Although the relationships of facilities and staff policy to service quality, employees' job satisfaction and pro social service behaviors appear to be obvious, this study is an initial step in exploring the existence of these relationships in terms of Halal-based service operations practices.

Results in this research constitute only an early step in understanding model of Halal certification practices and hotel performance. Additional research is needed to observe the relationships between the Halal certification practices towards organizational performance.Firstly, in order to enhance the validity and generalization of presented findings, future researchers can expand the scope of the research to different hotels, organization or industry.Besides that, it is recommended that it would be better if future researches to also use the qualitative approach such as interview for data collection. The future research may also include testing of other variables which might have significant effects on organizational performance such as packaging, labelling, advertising and legal requirement.

\section{Acknowledgements}

We would like to take this opportunity to express our sincere appreciation to Universiti Utara Malaysia for granting the research grant of RM6000 to enable this research to be accomplished.We would also like to extend our gracious gratitude to EDC-UUM hotel for invaluable information and facts that contribute to the success of this research.

\section{References}

Ackerman, F. (2000). Waste mangement and climate change. Local Environment, 5(2), 223-229. http://dx.doi.org/10.1080/13549830050009373

Amaratunga, D. D., Baldry, D., \& Sarshar, M. (2000). Assessment of facilities management: What next? Facilities, 18(1/2), 66-75. http://dx.doi.org/10.1108/02632770010312187

Barrett, P. (1994). Facilities management: Towards best practice. London: Blackwell Science.

Begum, R. A., \& Jacqueline, P. J. (2008). Environmental problems in Malaysia: A view of contractors perception. 
Journal of Applied Science, 8, 4230-4233. http://dx.doi.org/10.3923/jas.2008.4230.4233

BERNAMA. (2011). Malaysia to be more aggressive to dominate global Halal market. Retrieved July 7, 2012, from http://www.halalfocus.com

Brayman, A., \& Bell, E. (Eds.). (2007). Business Research Methods (2nd ed.). Oxford: University Press.

Cascio, W. F. (Ed.) (1992). Managing human resource: Productivity, quality of work life (3rd ed.). New York: Palgrove Macmillian.

Cohen, J. W. (Ed.). (1988). Statistical power analysis for the behavioral sciences (2nd ed.). New York: Erlbaum.

Collis, D. J., \& Montgomery, C. A. (1995). Competing on resources. Harvard Business Review, 73(4), 118-128.

Cooke, P., Heidenreich, M., \& Braczyk, H. J. (2004). Regional innovation systems: the role of governance in a globalized world. New York: Routledge.

Hair, J. F., Money, A. H., Samouel, P., \& Page, M. (2007). Research methods for business. England, West Sussex: John Wiley and Sons.

Halal Industry Development Corporation (2008). Halal industry programme: Halal internal auditing workshop. Kuala Lumpur.

JAKIM (2012). Halal Malaysia. Retrieved July 21, 2012, from http://www.halal.gov.my/v3/

Kaiser, H. E. (1974). An index of factorial simplicity. Psychometrika, 39, 31-36. http://dx.doi.org/10.1007/BF02291575

Kolovoes, K. G. (2006). Waste ammunition as secondary mineralizing raw material in Portland cement production. Cement Concrete and Residential, 28, 133-143. http://dx.doi.org/10.1016/j.cemconcomp.2005.10.001

Kromp, B. (1999). Carabid beetles in sustainable agriculture: a review on pest control efficacy, cultivation impacts and enhancement. Agriculture, Ecosystems \& Environment New York, 187-228. http://dx.doi.org/10.1016/S0167-8809(99)00037-7

Likert, R. L. (1961). The human organization. New York: McGraw-Hill.

Madeley, A. (1996). The performance of organisations and facilities management: An exploration into the opportunities afforded for facilities management to contribute toward corporate performance. University of Strathclyde: MSc dissertation.

Marzuki, S. Z. S., Hall, C. M., \& William, P. (2012). Restaurant managers' perspective on Halal certification. Journal of Islamic Marketing, 3(11), 47-58. http://dx.doi.org/10.1108/17590831211206581

Muchinsky, P. M. (Ed.). (1993). Psychology applied to work (4th ed.). California: Brooks/Cole Publishing Company.

Noordin, N., Noor, N. L. M., Hashim, M., \& Samicho, Z. (2009). Value chain of Halal certification system: A case of the Malaysia Halal industry. European and Mediterranean Conference on Information Systems.

Rahman, L. A. (2008). Shariah and Malaysia Halal certification system. Paper presented at the Halal Food Seminar, Universiti Sains Islam Malaysia.

Rajagopal, S., Ramanan, S., Visvanathan, R., \& Satapathy, S. (2011). Halal certification: Implication for marketers in UAE. Journal of Islamic Marketing, 2(2), 138-153. http://dx.doi.org/10.1108/17590831111139857

Salamon, M. (Ed.). (2000). Industrial relations: Theory and practice (4th ed.). Harlow: Prentice Hall.

Sekaran, U. (2003). Research methods for business: A skill building approach (4th. ed.). New York, John Wiley $\&$ Sons Inc.

Sekaran, U. (Ed.). (2000). Research methods for business: A skill-building approach (3rd ed.). U.S: John Wiley \& Son. Inc.

Zailani, S., Omar, A., \& Kopong, S. (2011). An exploratory study on the factors influencing the non-compliance to Halal among hoteliers in Malaysia. International Business Management, 5(1), 1-12. http://dx.doi.org/10.3923/ibm.2011.1.12

\section{Copyrights}

Copyright for this article is retained by the author(s), with first publication rights granted to the journal.

This is an open-access article distributed under the terms and conditions of the Creative Commons Attribution license (http://creativecommons.org/licenses/by/3.0/). 